\title{
Effect of nano silica coating concentration on reducing acrylic resin denture cytotoxicity
}

\author{
Gene Rizky Natalia Gunawan* ${ }^{\star}$, Titik Ismiyati** Haryo Mustiko Dipoyono** \\ ${ }^{*}$ RSGMP UNSOED Purwokerto, Central Java, Indonesia \\ Specialty Study Program of Prosthodontics, Faculty of Dentistry, Universitas Gadjah Mada, Yogyakarta, Indonesia \\ **Department of Prosthodontics, Faculty of Dentistry, Universitas Gadjah Mada, Yogyakarta, Indonesia \\ *JI DR. Soeparno, Karangwangkal, Purwokerto, Central Java, Indonesia, $₫$ correpondence: generizky@gmail.com
}

Submitted: $18^{\text {th }}$ July 2018; Revised: $11^{\text {st }}$ December 2018; Accepted: $14^{\text {th }}$ April 2019

\begin{abstract}
Acrylic resin is a denture base material mostly used in the fabrication of removable partial denture and complete denture because it is easy to process, economical and aesthetically satisfying. However, the acrylic resin has a weakness i.e. residual monomer content which causes cytotoxic effect to human cells. Nano-silica coating could be used on the acrylic resin to reduce residual monomer content. The purpose of this study was to determine the effect of nano-silica coating concentration on the cytotoxicity of acrylic resin denture base material. Twenty-four acrylic resin disc-shaped specimens ( $5 \mathrm{~mm}$ in diameter and $2 \mathrm{~mm}$ in thickness) were divided into 4 groups $(\mathrm{n}=6)$, i.e. control, group with application of $0.5 \%$, $1 \%$, and $2 \%$ nano silica coating. The specimens on the silica coating groups were silica coated using dip-coating method. After the coating was completed, the specimens were added into cell fibroblast culture (vero cell line). Cytotoxicity tests were done by MTT assay. The optical density was measured using ELISA plate reader to determine the percentage of cell viability. The highest mean of cell viability was shown in $0.5 \%$ concentration $(96.78 \pm 1.71)$ and the lowest mean was shown in the control group (80.32 \pm 6.53 ). One-way ANOVA showed that there were significant differences among these groups. LSD tests showed that there was significant difference among all of the groups. This study concluded that nano silica coating concentration has a significant effect on the cytotoxicity of acrylic resin denture base materials.
\end{abstract}

Keywords: acrylic resin; cytotoxicity; fibroblast cell; nano silica coating

\section{INTRODUCTION}

Denture base is a part of the denture that rests on the gingival connective tissue and on which artificial teeth are placed. Various types of the base have been used for denture fabrication, but there has been no type that can meet the ideal denture base requirements. Acrylic resin is a denture base material mostly used in the fabrication of removable partial denture and complete denture because it is easy to process, economical and aesthetically satisfying. ${ }^{1}$

Polymethylmethacrylate (PMMA) or acrylic resin is a highly acceptable material in dentistry. Since 1946, 98\% denture bases were made of PMMA. ${ }^{1}$ Heat-cured acrylic resin is used for denture base material, where self-cured acrylic resin is mostly used for denture reparation. ${ }^{2}$ Polymethymethacrylate meets the ideal denture base requirements which are: dimensional accuracy and stability, insolubility in oral environment, high biocompatibility, satisfying aesthetic, good color stability, ease of manipulation, and relatively low cost. ${ }^{3}$ Nonetheless, acrylic resin also has a weakness i.e. residual monomer content which can cause cytotoxic effect to human cells. ${ }^{4}$ Residual monomer, that is methylmetacrylate (MMA), is released in saliva and may irritate oral mucosa and cause hypersensitivity, indicated by redness, burning sensation, pain-related swelling, and cell cytotoxicity. ${ }^{5}$

Research in chemical industry for the recent 10 years focused on adding nanoparticles into acrylic resin to produce new material. ${ }^{6}$ Nano oxide particles such as titanium oxide $\left(\mathrm{TiO}_{2}\right)$, silicon dioxide $\left(\mathrm{SiO}_{2}\right)$, aluminum oxide $\left(\mathrm{Al}_{2} \mathrm{O}_{3}\right)$ and zirconium oxide $\left(\mathrm{ZrO}_{2}\right)$ are the most commonly used particles to increase denture base strength. ${ }^{7}$ 
Surface modification of acrylic resin denture base using silica coating has been widely observed to develop acrylic resin denture base with higher biocompatibility by reducing the adherence of pathogenic microorganisms and improving the surface properties of acrylic resin. ${ }^{8,9}$ The application of silica coating was highly observed because the use of coating materials do not change the bulk properties of acrylic resin, but can modify the surface properties. ${ }^{10}$ Silica coating with $2 \%$ concentration was used to coat acrylic resin denture base and has been proven to reduce the adherence of Candida albicans. ${ }^{8}$ Silica coating on artificial teeth has been proven to improve the wear resistance of denture. ${ }^{9}$

The use of an appropriate concentration of silica as a coating material is important. Silica has high surface tension and reacts chemically so the silica particles tend to agglomerate. Silica agglomeration may cause the coating layer to loose easily. ${ }^{11}$ Nanoparticles have higher cytotoxicity than micro-sized particles characterized by increased concentrations of reactive oxidative species (ROS). ${ }^{12}$

Silica-based nanoparticles are widely used in many fields, raising questions about the possible side effects of this material on human cells. ${ }^{13}$ The silica of which the size is less than $25 \mathrm{~nm}$ is biocompatible and not toxic to cells, ${ }^{14}$ whereas another study indicated that silica with a size less than $100 \mathrm{~nm}$ causes acute toxicity. ${ }^{15}$ The results of the study on the cytotoxic effects of silica nanoparticles showed an opposite result. Therefore it is necessary to conduct further research on the biocompatibility of silica nanoparticles. According to ISO 10993-5, a material is not classified as toxic if the percentage of cell viability after exposure reaches more than $70 \% .{ }^{16}$ The purpose of this study was to determine the effect of nano-silica coating concentration on the cytotoxicity of acrylic resin denture base materials.

\section{MATERIALS AND METHODS}

This study was a laboratory experimental study using 24 acrylic resin disc-shaped specimens ( $5 \mathrm{~mm}$ in diameter and $2 \mathrm{~mm}$ in thickness). The specimens were divided into 4 groups $(n=6)$ : control and experimental groups: $0.5 \%, 1 \%$ and $2 \%$ nano-silica coating (EC 001328/KKEP/FKG-UGM/ $E C / 2018)$. The materials used in this study were: heat-cured acrylic resin (QC-20, Dentsply), silica nanoparticles (Sigma, Aldrich), ethanol as solvent for the coating solution, silane (Ultradent Silane, Fondaco), M199 (Sigma Aldrich) for cell culture medium, and fibroblast cell culture (Vero ATCC CCL-81).

The acrylic resin specimens were produced according to the manufacturer's recommendation of packing and polymerization procedure from QC-20 (Dentsply) using conventional water bath technique at LPPT, Universitas Gadjah Mada. Silica coating solutions at $0.5,1$, and $2 \%$ concentrations were prepared by dissolving $0.5,1$, and 2 gram of silica nanoparticles into $100 \mathrm{ml}$ ethanol, respectively. Silane containing 3-methacryloxypropyltrimethoxysilanes was applied to the specimens in the experimental groups and left dried. The specimens were coated by silica coating solution using the dip-coating method, and heated in an oven (Panasonic, Japan-220V/50Hz) at $70{ }^{\circ} \mathrm{C}$ for 10 minutes. $^{17}$

In vitro cell toxicity was studied by seeding density of $2 \times 10^{4}$ cells / $100 \mu \mathrm{L}$ onto 96 well plates. ${ }^{18}$ and incubated for 24 hours. Subsequently, the acrylic resin was placed and incubated for 24 hours. ${ }^{16,19}$ The microplate was added $100 \mu \mathrm{L}$ 3-(4,5-dimethylthiazol-2-yl)-2,5-diphenyltetrazolium bromide) tetrazolium substrate and $100 \mu \mathrm{L}$ SDS$\mathrm{HCl}$ substrate then incubated in the dark for 24 hours and then placed on the plate reader with a wavelength of $550 \mathrm{~nm}$, the OD value (Optical Density) was obtained from the calculation of the number of formazan crystals. Cytotoxicity was measured by the cell viability relative to the control with the following formula: ${ }^{15}$

$\%$ viable cell $=\frac{O D \text { treatment }-O D \text { medium }}{O D \text { control }-O D \text { medium }} \times 100 \ldots \ldots \ldots \ldots \ldots \ldots \ldots \ldots \ldots \ldots \ldots \ldots \ldots \ldots \ldots$

The data obtained were analyzed by a oneway ANOVA with a $95 \%$ significance level. If ANOVA results indicated a difference, then the post hoc 
Majalah Kedokteran Gigi Indonesia. December 2019; 5(3): 126 - 130

ISSN 2460-0164 (print)

ISSN 2442-2576 (online)

LSD test was performed to determine which groups had significant mean differences.

\section{RESULTS}

The mean and standard deviation of the viability of Vero cell after exposure to an acrylic resin plate with $0.5 \%, 1 \%$ and $2 \%$ nano-silica coating can be seen in Table 1. The requirements to be met in the one-way ANOVA test were: data with normal distribution and homogeneity invariance. The normality test using Shapiro-Wilk test showed that $p$-value was 0.008 $(p<0.05)$. This shows non-normally distributed data. Furthermore, data transformation was done with the transformation of $\log 10$ and the result was $p 0.192$ $(p>0.05)$ so it can be concluded that the cytotoxicity variable was normally distributed.

Based on the results of the one-way ANOVA test (Table 2), the mean differences among the groups were significant $(p<0.05)$. The LSD post hoc test results in Table 4 showed that there was a significant difference in the mean cell viability in all pairs of groups with $p<0.05$.

Table 1. Percentage of cell viability after exposure to acrylic resin with nano silica coating in various concentrations (mean, standard deviation (SD))

\begin{tabular}{ll}
\hline Groups & Mean \pm SD \\
\hline Control & $80.32 \pm 6.53$ \\
Coating $0.5 \%$ & $96.78 \pm 1.71$ \\
Coating 1\% & $91.81 \pm 5.92$ \\
Coating $\%$ & $86.16 \pm 2.39$ \\
\hline
\end{tabular}

Table 2. ANOVA summary of cell viability

\begin{tabular}{lccccc}
\hline & $\begin{array}{c}\text { Sum of } \\
\text { squares }\end{array}$ & df & $\begin{array}{c}\text { Mean } \\
\text { square }\end{array}$ & F & Sig. \\
\hline $\begin{array}{l}\text { Between } \\
\text { groups }\end{array}$ & 481.25 & 3 & 160.405 & 71.233 & $0.00^{*}$ \\
Within groups & 27.022 & 12 & 2.252 & & \\
\hline Total & 508.236 & 15 & & & \\
\hline
\end{tabular}

*. Significance level was designated at 0.05

Table 3. Post hoc LSD of cell viability

\begin{tabular}{lll}
\hline & Groups & Sig. \\
\hline Control & Coating $0.5 \%$ & $0.000^{*}$ \\
& Coating $1 \%$ & $0.000^{*}$ \\
& Coating $2 \%$ & $0.008^{*}$ \\
Coating $0.5 \%$ & Coating $1 \%$ & $0.011^{*}$ \\
& Coating $2 \%$ & $0.000^{*}$ \\
Coating $1 \%$ & Coating 2\% & $0.016^{*}$ \\
\hline
\end{tabular}

*Significance level was designated at 0.05

\section{DISCUSSIONS}

The result of the study showed that the group with $0.5 \%$ silica coating had the highest cell viability compared to all the other groups. All the groups with nano-silica coating had higher cell viability than the control group. This is possible because there is still a non-polymerized monomer called residual monomer at the end of the acrylic resin polymerization process. Residual monomer is a major factor affecting the denture base cytotoxicity. Residual monomers do not react perfectly and have the potential to cause an inflammatory response and hypersensitivity to the mucosal tissue. Residual methyl methacrylate monomer is a factor that affects the cytotoxicity of acrylic resin because it can cause allergic reactions and mucosal irritations of the oral cavity and reduce the amount of cell proliferation, thus resulting in increased cytotoxicity. ${ }^{20}$

Silica coating with $0.5 \%$ concentration had the highest viability percentage $(96.78 \pm 1.71) \%$ among all the groups because, at such concentration, nano-silica can have maximum monomer chain binding without agglomeration. The application of silica coating on hot-cured acrylic resin denture decreases the amount of residual monomer. ${ }^{21}$

At higher concentrations of nano-silica coating (in this study the concentrations of $1 \%$ and $2 \%$ ) cell viability decreased. This is because some of the coating particles clumped so the number of particles that can bind to the remaining monomer chain decreases. At high silica concentrations, only partial coating particles can bind to acrylic resins through silanes, so the non-binding coating particles will tend to agglomerate and then look like mist shadows on the coating layer..$^{10}$ This process then decreases the durability of the coating layer so the coating is easily removed. Silica at $3 \%$ concentration was found to be unstable and nondurable on acrylic resins.

The hydrogen bond is a contributing factor to nano-silica agglomeration..$^{22}$ This is due to the greater the concentration of nanoparticles in a suspension, the smaller the distance between the nanoparticles so the inter-nanoparticles interact with each other and agglomerate. ${ }^{23}$ Hydrophilic nanoparticles have a large interaction of particles because hydroxyl groups present on the surface of 
nanoparticles can induce the formation of hydrogen bonds. ${ }^{24}$

According to ISO 10993-5, a material is categorized as non-cytotoxic when the percentage of cell viability exceeds $70 \%$. Bajrami (2014) in his research categorized material cytotoxicity based on the percentage of cell viability; a. Not cytotoxic:> $90 \%$ cell viability, b.Mild cytotoxic: $60-90 \%$ viability, c. Medium cytotoxic: $30-59 \%$ viability, and Severe cytotoxic: $<30 \%$ cell viability. Based on the results of this study, it can be said that the group with $0.5 \%$ nano-silica coating concentration had the highest percentage of cell viability among the other groups, meaning that the $0.5 \%$ group was the group with the lowest cytotoxicity.

\section{CONCLUSION}

The conclusion of this study is the concentration of nano-silica coating affects the cytotoxicity of acrylic resin denture. The increased concentration of nano-silica coating decreases cell viability. Nano silica coating at $0.5 \%$ concentration has the lowest cytotoxicity. Based on the research that has been done, the researchers recommend conducting further research on the effect of nano silica-coating concentration on the cytotoxicity of acrylic resin denture base using dye exclusion methods to compare the results.

\section{REFERENCES}

1. Craig RG. Restorative dental materials $13^{\text {th }}$ Ed. St. Louis: CV Mosby; 2011.

2. Anusavice KJ, Phillips RW, Shen C, Rawls HR. Phillips' science of dental materials, $12^{\text {th }}$ ed. St. Louis: Elsevier; 2013. 165-166, 721-722.

3. Carr AB, Brown DT. McCracken's removable partial prosthodontics $12^{\text {th }}$ Ed. Singapura: Mosby Elsevier; 2012. 7, 106-107, 346.

4. Powers JM, Sakaguchi RL. Craig's restorative dental materials $12^{\text {th }}$ ed. St.Louis: Elsevier; 2012. 524-544.Combe EC and Grant AA. Notes of dental material, $6^{\text {th }}$ Ed. New York: Churchill Livingstone.; 1992. 26-28, 79-120, 157-161, 224, 262-269.
5. Alnamel HA, Mudhaffer M. The Effect of silicon dioxide nano fillers reinforcement on some properties of heat cured polymethylmetacryate denture base material. J Bagh College Dentistry. 2014; 26(1): 32-36.

6. Sodagar A, Bahador A, Khalil S, Shahroudi AS, Kassaee MZ. The Effect of $\mathrm{TiO}_{2}$ dan $\mathrm{SiO}_{2}$ nanoparticles on some flexural strength of polymethyl metacrylate acrlic resin. J Prosthodont Res. 2013; 57(1): 15-19. doi: 10.1016/j.jpor.2012.05.001

7. Azuma A, Akiba N, Minakuchi S. Hydrophilic surface modification of acrylic denture base material by silica coating and its influence on Candida albicans adherence. J Med Dent Sci. 2012; 59(1): 1-7.

8. Kamonwanon $\mathrm{P}$, Yodmongkol $\mathrm{S}$, Chantarachindawong R, Thaweboon, S, Thaweboon B, Srikhirin T. Wear resistance of a modified polymethyl methacrylate artificial tooth compared to five commercially available artificial tooth materials. J Prosthet Dent. 2015; 114(2): 286-292. doi: 10.1016/j.prosdent.2015.01.013

9. Yoshizaki T, Akiba N, Inokoshi M, Shimada M, Minakuchi S. Hydrophilic nano-silica coating agents with platinum and diamond nanoparticles for denture base materials. Dent Mater J. 2017; 36(3): 333-339. doi: 10.4012/dmj.2016-243

10. Zayed SM, Alshimy AM, Fahmy AE. Effect of surface treated silicon dioxide nanoparticles on some mechanical properties of maxillofacial silicone elastomer. Int J Biomater. 2014; 2014 : 750398. doi: 0.1155/2014/750398

11. Kim IY, Joachim E, Choi H, Kim K. Toxicity of silica nanoparticles depends on size, dose and cell type. Nanomedicine. 2015; 11(6): 1407-1416. doi: 10.1016/j.nano.2015.03.004

12. Jung EK, Kim H, An SS, Maeng EH, Kim MK, Song YJ. In vitro cytotoxicity of $\mathrm{SiO}_{2}$ or ZNO nanoparticles with different sizes and surface charges on human glioblastoma cells. Int J Nanomedicine. 2014; 9(2): 235-241. doi: $10.2147 /$ IJN.S57936 
13. Kumar R, Roy I, Ohulchanskky TY, Vathy LA, Bergey EJ, Sajjad M. In vivo biodistribution and clearance studies using multimodal organically modified silica nanoparticles. ACS Nano. 2010; 4(2): 699-708.

doi: $10.1021 / \mathrm{nn} 901146 \mathrm{y}$

14. Nishimori H, Kondoh M, Isoda K, Tsunoda S, Tsutsumi Y, Yagi K. Silica nanoparticles as hepatoxicants. Eur J Pharm Biopharm. 2009; 72(3): 496-501.

doi: 10.1016/j.ejpb.2009.02.005

15. ISO 10993-5. Biological evaluation of medical devices-part 5: tests for in vitro cytotoxicity, International Organization for standarization. Geneva; 2009. 30-34.

16. Amano D, Ueda T, Sugiyama T. Improved brushing durability of titanium dioxide coating on polymethylmethacrylate substrate by prior treatment with acryloxypropyl trimethoxysilane $\neg$ based agent for denture application. Dent Mater J. 2010; 29(1): 97-103. doi: 10.4012/dmj.2009-073

17. Ammerman NC, Beier Sexton M, Azad AF. Growth and maintenanace of vero cell lines. Curr.Protoc.Microbiol. 2008. 1-7. doi: 10.1002/9780471729259.mca04es11

18. Ahuja S, Babu J, Wicks R, Garcia-Godoy F, Tipton D. Cytotoxic effects of three deture base materials on gingival epithelial cells and fibroblast: an in vitro study. Int J of Experimental Dental Science. 2015; 4(1): 11-16.

doi: 10.5005/jp-journals-10029-1088
19. Celebi N, Yuzuglu B, Canay S, Yucel U. Effect of polymerization methods on the residual monomer level of acrylic resin denture base polymers. Polym Adv Technol. 2008; 19(3): 201-206. doi: 10.1002/pat.996

20. Suhono RS. Pengaruh silica coating pada plat gigi tiruan resin akrilik haet cured tehadap kekerasan permukaan dan monomer sisa. UGM Yogyakarta: Thesisl; 2018. 58.

21. Wang $Y$, Xiaojun W, Wei $Y$, Yuanming $Z$, Banghu $X$, Mingbo $Y$. Aggregate of nanoparticles: rheological and mechanical properties. Nanoscale Res Lett. 2011; 6(1): 114. doi: 10.1186/1556-276X-6-114

22. Tadano T, Rui Z, Yoshio M, Toru H, Shoichiro Y. A new mechanism for the silica nanoparticle dispersion-agglomeration transition in a poly(methyl methacrylate)/silica hybrid suspension. Polymer Journal. 2014; 46: 342-348. doi: 10.1038/pj.2014.6

23. Tahmasebpoor M, Ghasemi SA, Rahimvandi $\mathrm{N}$, Badamchizadeh P. Model based on electrostatic repulsion and hydrogen bond forces to estimate the size of nanoparticles agglomerate in fluidization. Ind. Eng. Chem. Res. 2016; 55: 12939-12940.

24. Wu X, Sacher E, Meunier M. The effects of hydrogen bonds on the adhesion of inorganic oxide particles on hydrophilic silicon surfaces. J. Appl. Phys. 2002; 86 (3): 1744-1748. 